\title{
ETHICAL EDUCATION AND MORAL THEORY
}

\author{
Vojko Strahovnik \\ Faculty of Theology, University of \\ Ljubljana, Slovenia \\ vojko.strahovnik@teof.uni-lj.si
}

Received: 20 April 2018

\begin{abstract}
One of the central questions of ethical education is the role that moral theory could or should play within it. This concerns not only the issue of pedagogical work with children, but also the establishment of professional education and training for teachers and other educators. Contemporary approaches to ethical education emphasise the importance of integrative models and methods, but the issue of moral theory within them has not been explicitly addressed at length. The aim of this paper is thus reflected in the following building blocks and steps. In the first part, I present the concept of ethical education and the field of moral theory. In the second part, I synthetically illuminate the importance of moral theory for ethical education.
\end{abstract}

Key words: ethics, moral theory, metaethics, ethical education, integrative approach

\section{Introduction}

This paper is concerned with the issue of the importance and role of moral theory in ethical education. The central problem is somewhat narrower, concerning the issue of the role of moral theory in the context of professional education and training of teachers and other educators. Modern approaches to ethical education, and hence to the education and training of educators, emphasise integrative methodologies (Silcock, Duncan, 2001). Thus far, concern regarding the role of moral theory has not been specifically clarified within them. The purpose of this contribution is multi-layered and consists of the following steps. First, I will briefly explain my interpretation of ethical education (§2), and I will further highlight some considerations regarding approaches 
to it (\$2.1.). In the next step, I will briefly outline the field of moral theory $(\S 3)$. Next, I will move on to the question of the significance and role of moral theory in ethical education and synthetically illuminate its significance (§4). In subsection 4.1, I will outline the answer to this question in relation to particular domains of moral theory. Lastly ( $\$ 5)$, I will conclude with some reflections on the intersection of philosophy, morality, and education.

\section{What is Ethical Education}

Ethical education ${ }^{1}$ encompasses all dimensions of education and the educational process that are directly or indirectly related to the ethical dimensions of our lives and can be either planned, designed, guided, or monitored with the appropriate educational methods and tools, or are an implicit part of the educational processes and thus often remain unconscious, unexamined, or unintentional. Ethical education thus, inter alia, focuses on promoting ethics and values (justice, equality, dignity, inclusiveness, human rights, etc.) as a part of education, nurturing a respectful attitude towards others (both individuals and communities alike), cultivating the positive formation of character, building capacities for reflective and informed moral judgment, putting one's beliefs and values into practice, etc. Education is an inherently value-laden process, both in terms of what is conveyed (content) as well as in terms of the way it is conveyed (methods), its consequences (educational outcomes), and relationships that are formed in the educational context (Strahovnik, 2016).

"Education implies that something worthwhile has been intentionally transmitted in a morally acceptable manner." (Peters, 1970, 25)

Ethical education takes this internal or implicit ethical dimension, reflects upon it, and sets it as an explicit aim. This is connected with a recognition that the ethical or value-laden aspect of the educational process cannot be excluded from this process anyway, and that the idea of an alleged value-neutral education is a delusion (Strahovnik, 2016;

${ }^{1}$ Different terms are used to designate this domain or parts of it, including ethics education, moral education, values education, education for values, character education, etc. In this paper, I will understand ethical education in its broadest sense and also use this term for all of its aspects unless otherwise indicated. 
Ainsworth, Johnson, 2000). Even if it were possible, it would be undesirable, and it would be counterproductive if attempted. Education, especially early education, is one of the most fundamental elements in supporting the development of autonomous, caring, resilient individuals that will contribute to communities both locally and globally. Ethical education can play an important part in nurturing such individuals.

The oftmentioned goals of ethical education are the following: (i) to promote ethical reflection, attentiveness, autonomy, and responsibility in children as well as all other members of an educational community being established in a given educational setting; (ii) to enable children to examine and understand important ethical principles, values, virtues, and ideals, and to equip them with the intellectual and moral abilities (critical thinking, reflection, comprehension, appreciation, compassion, valuing, etc.) needed for responsible moral judgment, decision-making, and action; (iii) to guide children to explore different values, different dimensions of values, and different moral justifications on the basis of these values and combine them into a guiding unity; (iv) to direct children towards a commitment to recognised basic values and the fundamental meaningfulness of life, while at the same time cultivating their self-image and feeling of self-worth (Centa, 2013, 444-446); (v) to enable children to overcome any possible prejudices, biases, discrimination, and other unethical attitudes and practices, while simultaneously helping them create an appropriate, respectful attitude towards themselves, others around them, society, and the environment; (vi) to promote cooperative, collaborative behaviour and to deepen the motivation for creating a group, class, or school environment as a genuine ethical community (Globokar, 2018, 558); (vii) to build character (including intellectual and moral virtues) in children such that it will enable them to flourish and to achieve a morally acceptable, personally satisfying good life (the ancient ideal of eudaimonia), and; (viii) to develop and reflect on how to situate children and ourselves as members of local and global communities, one of the tasks of which is to contribute to them (Strahovnik, 2016).

This broad interpretation of ethical education positions itself at the heart of what John Dewey defines as the general goal of education, which amounts to "the formation of a cultivated and effectively operative good judgment or taste with respect to what is aesthetically admirable, intellectually acceptable and morally approvable" (Dewey, 1980, 262). To further specify this, we may add that 
“... [o]ne purpose of moral education is to help make children virtuous - honest, responsible, and compassionate. Another is to make mature students informed and reflective about important and controversial moral issues. Both purposes are embedded in a yet larger project - making sense of life." (Nord, Haynes, 1998)

Ethical education incites individuals to make values relevant to, for, and in their lives in a concrete social context and in an experiential and expressive manner. The precise way to best achieve all of these goals remains open, but what most can agree upon is that these processes must go beyond a straightforward inculcation of values or passive assent based on authority. In order to take further steps in this regard, I will examine some methodological approaches to ethical education.

\subsection{Methodological Approaches to Ethical Education}

As we saw above, one issue that remains open is a question of approaches to ethical education, both in the context of the educational process as well as in the context of professional education and continuing training of teachers and other educators. In the area of ethical education, several possible methodological approaches to this are apparent. These include the rather direct transfer and integration of values, the content of the educational process, school practices or policies, and more open and reflective approaches that are mainly related to philosophy with children and critical thinking. Another set of approaches focuses on the individual aspects of morality (the approach of ethics of care, an empathy-based approach (cf. Gerjolj, 2015), ethical education focused on cognitive moral development, character education, infusion approach, etc.) or focuses primarily on ethical education through ethical action(s) (experiential learning, community-oriented projects and activities at school, etc.).

Some views also specifically focus on moral theory, arguing that ethical education must be centred around moral theory. Warnick and Silverman note that

“... [a]nother way of looking at ethics education, a favourite among traditional philosophers, is to see professional ethics education as an opportunity to learn about philosophical theories of ethics. Under this approach, the students are taught one or more ethical theories (usually utilitarianism, Kantian deontology, or care theory) and are then taught to apply these theories to resolve, or at least inform, ethical dilemmas." (Warnick, Silverman 2011, 274) 
We will return to this aspect later on, especially when discussing professional education and the training of teachers and other educators.

Recently, more and more approaches or proposals have been developed aimed at multi-dimensional, holistic, and integrative approaches that combine both traditional educational goals and recent lessons from moral psychology and other sciences. Part of this development was also the transformation of the values clarification approach method (Simon, Howe, Kirschenbaum, 1972), which has moved away from the framework of non-binding moral pluralism as the basis of the free personal choice of values in the process of their understanding, instead taking a more holistic approach that recognizes the limitations of the initial model. Kirschenbaum thus later highlights four aspects or dimensions as that form this larger integrated whole. As concerns content, comprehensive ethical education includes both personal and social values, and both ethical and moral issues as well. Secondly, an integrative approach to ethical education should include diverse methodological approaches. Thirdly, this kind of approach to ethical education extends beyond teaching and learning as part of an individual subject and encompasses the entire school domain, including all subjects, as well as the remainder of school life and activities. Finally, the holistic integrative approach involves not only children and their teachers or educators, but the whole community and other institutions as agents of ethical education (Kirschenbaum, 1992, 775; Žalec, 2013, 75-77).

In line with this development, Silcock and Duncan (2001) highlight the following prerequisites for ethical education and values. (1) Process condition: the most appropriate circumstances for the integration of ethics and values within the school into the lives of children must, at least in part, include their voluntary commitment at a certain stage of this process. This simultaneously means recognising their autonomy, ability, and the value of personal choice in accordance with their moral development. (2) Conceptual condition: ethical education must lead to personally transformed relationships between the child and learning topics and content that is considered valuable, which means that the shift from belief to motivation and action presupposes the construction or conscious transformation and process of commitment, which is transformative for life. (3) Contextual condition: there must at least be partial coherence or consistency between the values, virtues, ideals, or 
criteria of ethical education, as well as broader socio-political frameworks. Internal inconsistencies in this framework regarding the content and goals of ethical education should be minimized (Silcock, Duncan, 2001, 251).

This integrative approach can also attain an essential balance between the individual and societal aspects of ethical education.

"As Socrates would have it, the philosophical examination of life is a collaborative inquiry. The social nature of the enterprise goes with its spirit of inquiry to form his bifocal vision of the examined life. These days, insofar as our society teaches us to think about values, it tends to inculcate a private rather than a public conception of them. This makes reflection a personal and inward journey rather than a social and collaborative one and a person's values a matter of parental guidance in childhood and individual decision in maturity." (Cam, 2014, 1203)

Developing ethics and values together in an educational setting fosters this collaborative perspective, enabling the individual to gain several different and comprehensive perspectives on ethical issues. Another reason for this manner of integration is to put a focus on the community, beginning from the "community of inquiry/enquiry" as promulgated by the philosophy with children approach, followed by other forms of community, as this methodology is embedded with values. This complements the ancient focus on the "life well lived" with that of "living together". What ultimately matters, Alasdair MacIntyre claims, "is the construction of local forms of community within which civility and the intellectual and moral life can be sustained" $(1984,224)$.

\section{A brief delineation of moral theory}

One simple way of defining moral theory or metaethics is as a field of moral philosophy that seeks to answer the most basic questions about the very nature of morality. However, this definition is not fully telling and requires further elaboration. The whole field of moral philosophy is divided into three levels: metaethics, normative ethics, and applied ethics. It is most meaningful to distinguish between the upper level and the lower two by saying that metaethics primarily deals with and questions the nature of morality (ethical issues of the second order), while normative and applicative ethics deals with its content (ethical issues of the first order), which also prevails in our everyday moral thoughts and 
practices. For example, if we ask ourselves what is morally valuable, what types of actions are moral duties, what virtues we should cultivate in the community, what the moral status is of certain types of actions or practices (e.g. euthanasia, death penalty, eating animals, gene manipulation etc.), these are normative or substantive issues on the general or applied level. On the other hand, metaethics questions the very foundations of these substantive issues, e.g. what it means to say that something is morally worthy or morally obligatory, whether there are independent, objective answers to these questions, how we can attain moral knowledge or justify our moral judgments, how our moral views and attitudes are related to motivation and action, etc. (Strahovnik, 2018).

The boundary between moral theory and substantive normative ethics is not and cannot be precisely drawn or defined, and the two are not separate. In the in-between domain, there are questions related to moral responsibility, free will, and motivation for moral action. Our common moral thought and language often simply does not deal with substantive issues, instead presupposing certain metaethical views, or at least leading to open questions. The same can be said of the history of moral philosophy itself for the most part, in which these two types of questions were not strictly separated into specific areas of moral philosophy as such. The theories of individual authors provide both answers to the substantive questions of ethics about how we must live, what to value, and what to strive for, as well as interpretations of various aspects of the nature of morality, e.g. regarding the sources of moral knowledge or the connection between moral judgments and action. A good example of this are Plato's dialogues, which usually open and address both types of questions. An important break within this tradition emerged with the work of G.E. Moore, particularly his book Principia Ethica (1903), in which he clearly distinguishes between the two mentioned types of questions. His starting point is that moral philosophy must first answer the basic metaethical questions (for example, about the definition and meaning of fundamental ethical concepts, in particular the concept of good) so that it can then deal with substantive questions and answer them (for example, which things have intrinsic moral value and what actions are morally right). Metaethical or moral-theoretical problems take priority - not in terms of their importance, but methodologically - over substantive issues. This kind of setting for moral philosophy subsequently led this division to broaden into a wide gap, and moral philosophers began to focus almost exclusively on purely theoretical 
questions, particularly the question of a more appropriate analysis of the meaning and role of moral sentences as they appear in ordinary speech and the conceptual analysis of the key moral expressions that appear in them (Strahovnik, 2018). Moral theory began to dominate over the entire field of moral philosophy and substantive issues were pushed out of it until the return of substantive moral philosophy in the 1960s and 1970s, especially in the form of applied ethics (animal ethics, bioethics, theories of justice).

The basic questions posed by moral theory can be divided into five domains that refer to questions about: (1) the existence and nature of moral reality (moral properties and facts); (2) the meaning and role of moral expressions and judgments; (3) the attainability of moral knowledge and the nature of moral justification; (4) practical and motivational aspects of moral judgments, and; (5) questions regarding moral experience. These can be further elaborated in the following way.

(1) Moral metaphysics: What is the nature or metaphysical foundation of moral judgments? Are there moral properties and are there moral factors? If so, what are they or what types of them are there? How are moral properties related to or linked to natural properties (such as pleasure and pain)? Can moral properties be reduced to natural properties, and can moral truths be reduced to natural truths?

(2) Moral semantics or theory of meaning: What is the role of moral judgments or moral language? Is this role descriptive, or do moral judgments play the role of expressing our commitment, norms, or rules (prescriptive role) or our emotional attitude towards the objects of these judgments (emotive or expressive role)? Can we ascribe truth values to moral judgments, and what are the truth conditions for these judgments? What do the terms "good", "bad", "morally right", "morally permissible", "morally wrong", etc. mean? How are moral concepts related to each other?

(3) Moral epistemology: Is moral knowledge at all attainable? If so, in what way, and if not, why? If there are moral facts, how are they cognitively attainable? Can we justify our moral judgments, and in what way? What is the structure and functioning of our moral thinking and evaluation? 
(4) Moral psychology: What are moral judgments? Are they beliefs or other, non-cognitive mental states, or maybe even some special mental states that are a composite of the aforementioned types? What is the psychological origin of moral judgments? How are our moral judgments linked to our motivation and our actions? Is there an essential link between the two in the sense that a sincere moral judgment also means that we will always be motivated to act in accordance with it? If this is not the case, then what source of our moral motivation would explain the connection between morality and its practical importance?

(5) Moral phenomenology: What is the nature of moral experience (for example, a sense of duty, recognition of moral value, or a sense of moral guilt and shame), and how does it differ from other types of experience? What can qualitative experience associated with moral judgment and action reveal to us regarding the nature of morality itself? (Strahovnik, 2018)

\section{The importance of moral theory for ethical education}

The question of the importance of moral theory or metaethics to ethical education will now be addressed. Ettenberg Aaron discusses formalist(ic) ethics in this regard:

“The term 'formalist' has been used to describe the methods and assumptions underlying the works of contemporary moral philosophers such as R. M. Hare, William Frankena, R. S. Peters, John Rawls. The philosophers thus classified do not by any means comprise a monolithic bloc; the differences between them are varied, serious, and complex. Nonetheless, they are united in their belief morality may be described in purely formal terms, irrespective of content." (Ettenberg Aaron, 1977, 514)

In the context of this interpretation of ethics, moral judgments are those that meet certain formal criteria (for example universality, generality, neutrality, finality, publicity, etc.), or which can themselves be derived from such criteria. This approach to ethical education, on the one hand, avoids the danger of indoctrination and the imposition of values as it focuses solely on the development of mental abilities that are directly related to these formal criteria and the "form" of morality, rather than the content of morality. However, there are some serious problems 
with this approach. First of all, it supposedly involves the reduction of moral philosophy, as well as wider moral thought, to moral theory or metaethics; this has several negative consequences in the field of ethical education and related training and approaches, one of which is the fact that this field is becoming dominated by abstraction and moral relativism. Second, Ettenberg Aaron points out that this image of ethical education presupposes that the domain of morality is completely autonomous and unconnected with other domains of philosophy or of life more generally.

"The primary purpose of moral education is to increase the students' ability to make intelligent, thoughtful, and responsible choices in actual situations; and, in actuality, values not so neatly separated from facts. Moral discussion which confines itself to questions of principle and avoids questions of fact is likely to become pedantic and sterile." (Ettenberg Aaron, 1977, 519)

Lastly, this approach unduly identifies the justification of our moral judgments with moral decision-making (decision-making and moral actions according to them). Therefore, as an alternative, she advocates Dewey's philosophy-based approach, which emphasizes concreteness, practicality, experientiality, life-relatedness, and syntheticity in relation to various views on morality, thus also emphasising the experiential aspects of morality and specific life situations (Ettenberg Aron, 1977, 514-532).

Above (in section 2.1.), I referenced a similarly sceptical and defiant view of the role of moral theory. However, such views and suggestions are based on the erroneous assumption of moral theory's clear division and independence from substantive ethics. Despite the aforementioned development of moral philosophy in the $20^{\text {th }}$ century, recent decades have seen an increasing number of appeals to bring metaethics and normative ethics closer together in order to achieve a firm, convincing, and defensible philosophical ethics. The question of the nature of normativity is shown to be central; metaethics and normative ethics address the very same question, only from different perspectives. For example, regarding ethics, Darwall says that

“... although metaethics and normative ethics focus on different issues, systematic ethical philosophy thrives when these areas are brought into dynamic relation and pursued in an integrated way we might call 'philosophical ethics'-framing normative ideals we can accept in light of both the best normative reasons as we see them and an adequate philosophical understanding of 
their subjects and of the possibilities for knowledge or justified acceptance in this area." (Darwall, 2006, 25, cf. Gewirth, 1968)

If ethical education endeavours to encompass ethics as a whole, metaethics or moral theory must consequently also be seen as an indispensable component of ethical education.

Along with this line of reasoning and within the framework of their integrated model of the interpretation of ethical education, Sanger and Osguthorpe suggest four types of assumptions: psychological, moral (theoretical, metaethical), educational, and contingent assumptions or factors. (Their overall framework is entitled "A framework for understanding the underpinnings of approaches to moral education".) The moral or theoretical assumptions further include questions about the nature and scope of morality, about moral psychology, as well as normative questions about what is good, morally right, virtuous, caring, etc.

"Any given approach to moral education must make or imply some assumptions about the nature or scope of morality in order to refer to moral education at all." (Sanger, Osguthorpe, 2005, 64)

Understanding these dimensions is of great importance to those very processes in the classroom or group that are related to moral dialogue or discussion.

At the same time, they point out that metaethics and a set of related resources about it have in fact not yet been systematically exploited in the context of ethical education, but rather are often marginalized. Similar remarks and appeals are also made by some other authors.

"If the Philosophical Ethics approach was taken [as a model of ethical education $-\mathrm{n}$. VS], ethics in school would consist in the students engaging in normative ethics and applied ethics, but to some extent also meta-ethics. The idea of engaging is of great importance here because it is not so much a question of teaching students theories about normative ethics [...] but rather of the students themselves doing normative ethics (or metaethics) in the sense of engaging in trying to answer the moral questions themselves, of scrutinizing different arguments and positions, and so on." (Gardelli, Alerby, Persson, 2014, 18)

Similarly, Scales includes metaethics in his proposal of the socalled ethics across the curriculum approach. One key reason justifying this is that pupils may otherwise be uncritically pushed into a false dilemma between moral dogmatism on the one hand and moral relativism 
on the other because they lack a sufficient understanding of the nature of morality and views of it.

"Theory and foundations are important components of any course which calls itself an ethics course. Of course we want to present students with the ambiguities of applied ethics. Of course we want to make them formulate and express their sincere moral convictions and to recognize the sincerity of those who hold different convictions. But without theory, without some attempt to ask 'Well, why should we agree with that?' and then 'And why should we accept that?', without a serious engagement with the process of establishing a coherent set of moral beliefs and justifications [...] students are left either with unsupported codes or with dueling intuitions." (Scales, 2005, 10)

\subsection{Domains of moral theory and their relevance to ethical education}

We can further elaborate on the importance of moral theory to ethical education by delving into specific domains of metaethics and highlighting their significance.

Moral metaphysics helps us understand different views of or way to conceptualise the existence of moral properties and facts, which is especially important if we enter into a debate on whether our moral judgments are objective and moral truths are independent of us. Moral semantics draws attention to the importance of questions about the significance of moral judgments and the role of our moral language or speech. Take the example of a simple moral judgment: "The torture of a sentient animal merely because of our own pleasure is morally wrong or impermissible." What mental state does this judgment reflect and what is its primary role? One view claims that this and other similar moral judgments are, primarily, beliefs (or express beliefs), and that, like all other beliefs, moral beliefs can be either true or false, and their semantic role is thus descriptive because they aim at the moral reality that we try to capture with these judgments. As regards the judgment above, it could be said that it expresses our belief that we ascribe the property of moral impermissibility to such actions of cruelty, and that such a belief is consequently either true or false if this is truly so. All this is contrary to views that advocate the interpretation that moral judgments are not and do not express beliefs, but rather other non-cognitive states such as our feelings, desires, attitudes, approval, acceptance of a chosen general moral norm (or a system of such norms), commands, or a combination 
of them. As such, moral judgments cannot be (in the most immediate sense) true or false, since this is merely a feature of genuine beliefs that are descriptive. Moral judgments do not serve to describe the moral properties of the objects of these judgments, which means that their primary role is not to declare something about the world and cannot be regarded as simply true or false from this point of view. Emotivism thus argues that moral judgments are the expression of our feelings, that this is why they are primarily about expressing emotional attitudes towards the objects of these judgments, and that such use of moral language in the interpersonal space also serves to influence the emotions and attitudes of others. Prescriptivism advocates the view that moral judgments are primarily a form of prescription or command, and that e.g. our example above of a particular moral judgment means our firm commitment against the ill-treatment of animals; this is also used to inform others that we do not approve it (in the sense that this also includes an appeal or command not to act in this way). Norm-expressivism is the view that moral judgments, like normative judgments, express the subject's acceptance of the system of norms or rules (e.g. which is such that it includes, inter alia, the impermissibility of cruelty against animals) (Strahovnik, 2018). This discussion is highly important to a thorough understanding of our moral speech and moral thought, which certainly falls within the fundamental themes of ethical education. It is also key to the understanding of moral disagreements and possible ways to resolve or address them.

Moral epistemology poses the question of whether and how we can talk about moral knowledge. It also deepens our understanding of the role of moral intuition in moral judgments. The latter is particularly important in the context of discussing cases of moral dilemmas, moral conflicts, or thought experiments, which is an approach that is recurrent in ethical education. In the context of ethical education, thought experiments can be sensibly used for many purposes (Strahovnik, 2014). The use of cases of moral dilemmas (real or imagined) is even more frequent. In both cases, the core of this activity is the elicitation of our moral intuitions and reflection on them. One of the advocates of this approach to ethical education is Strike, who emphasizes that it must focus on understanding basic ethical concepts and developing talents and skills related to the moral discussion, which includes moral intuitions, moral principles, and other assumptions we must take into account and reflectively balance. The primary role of ethical education is not the 
transfer of values or principles, but the promotion of moral reflection, moral sensitivity, and moral dialogue on given ethical issues. At the same time, Stike maintains that ethical education must be cultivated on the basis of case studies; at the heart of this usually lies an individual moral principle we would like to highlight, because

"... too much detail can be confusing and distracting. Material that is not relevant to the moral principle involved should not be included. Cases are more like diagrams in a science text than literary works. Their point is to simplify the world so as to focus attention on relevant facts and issues." (Strike, 1993, 113)

Similarly, thought experiments can be employed in the context of ethical education, while metaethics and aspects of moral epistemology can help us comprehend how to understand them and how to use them. In moral philosophy, thought experiments and examples of moral dilemmas are often used as counter-examples or for reductio ad absur$d u m$ in relation to a certain normative theory or moral point of view. In the context of ethics education, this also means the use of aporia in teaching, where teacher and student can clear the way for further thinking and reflection. Secondly, they can function as intuition pumps in the sense that they elicit responses from us such that we are then inclined to draw a particular conclusion on the basis of them. Again, in the context of education, this relates closely to the creation of reflective, engaged, stimulating involvement and critical reflection. Thirdly, they can be used as clarification devices, which serve to enhance our understanding by enabling us to differentiate distinct concepts and principles that have been heretofore conflated or vague. This is also crucial in the process of education, since it paves the way for a proper explanation of the subject matter and the organisation of knowledge. Lastly, they can serve as re-imaginings, enabling us to foster a debate or a given dispute in some novel way, surpassing our fixed presuppositions and commitments (Strahovnik, 2014). This fosters students' imaginations and enables them to move beyond their deeply-seated beliefs (Walsh, 2011), thus also making it easier to bridge the gap between moral theory and practice or actual cases. However, caution is of course required, as moral intuitions can be easily influenced and linked to various subdomains such as moral principles and rules, to the details of a specific case, to relationships with others, to the non-moral aspects of a situa- 
tion or example, to pre-existing, deeply-rooted biases, etc. (Burns et al., 2012; cf. Horgan, Potrč, Strahovnik, 2018, for a view on epistemic virtues and rationality in relation to our background knowledge and pre-existing epistemic commitments).

Moral psychology particularly addresses questions about the connection between moral judgments and the motivation for action; in this sense, it is a direct reverberation of the ancient question of why we should be moral. According to our everyday moral experience, we can begin from the recognition that our moral judgments usually (or at least very often) motivate us to act in accordance with them, or, in the event of a conflict between different motivations, we would comply with them in the absence other considerations. We can also say that our sincere moral judgments have a rational authority over us because they give us good reasons to follow them in our actions, even though some of our actions are not necessarily in our own interest or we have no desire to perform them. We would doubtlessly question the sincerity of the moral beliefs of someone who e.g. argues that a particular type of act is immoral while consistently acting contrary to this declaration. The question is what the nature of this connection is. One view argues that this connection is internal or essential and that moral beliefs are intrinsically linked to the motivation for action, while another view understands morality as being linked by motivation through an external factor at best, such as fear of punishment, our desires, preferences, interests, natural empathy with others, etc.

There is ample empirical evidence suggesting that explicit moral judgments hardly have any authority over us when it comes to action and that the link from moral judgments to motivation for action is embedded in a wider domain of motivational factors. All of this favours the ethical action approach to ethics (Roew, 2017). Nevertheless, the question of moral motivation or motivation for moral action lies at the heart of ethical education. Finally, moral phenomenology provides us an understanding of the qualitative, experiential aspects of morality, i.e. subjective experiences, responses, and states that accompany moral judgment, decision-making, and action (Strahovnik, 2018). These are all interesting and relevant topics for ethical education that are also vividly depicted in great works of art and stories that are embedded in our lives. 


\section{Conclusion}

All of the aforementioned topics and questions about the nature of morality are an element of ethical education, since they cannot be avoided in the moral discussion, and furthermore often appear explicitly in it (one of the questions that frequently arises is usually related to moral relativism). Therefore, it is reasonable to incorporate moral theory or metaethics into it, especially in the professional education and training of teachers and other educators. Martha Nussbaum sees the role of philosophy in education particularly in relation to the fact that "good" philosophy often enables us to think of a case or situation from a critical point of view, both within ourselves and our lives, and that therefore moral theory can help us to reveal, recognise, and understand the relationships that "have eluded us in our daily thinking" (2000, 253). I have shown above that, on the basis of similar considerations, a holistic and integrative approach to ethical education should also meaningfully incorporate the aspects of moral theory or metaethics. ${ }^{2}$

\section{Bibliography}

Ainsworth, Stuart; Johnson, Andrew (2000), "The TTA Consultation Documents on ITT: What, No Values?", in: Gardner, Roy; Cairns, Jo; Lawton, Denis (ed.), Education for Values. Morals, Ethics and Citizenship in Contemporary Teaching, London: Kogan and Page, pp. 159-186.

doi: https://doi.org/10.4324/9780203416730_chapter_11

Burns, David P.; Leung, C.; Parsons, L.; Singh, G. and Yeung, B. (2012), "Limitations of the Case Study Approach to Pedagogical Ethics Education", Transformative Dialogues: Teaching \& Learning Journal, 6(1), pp. 1-10.

Cam, Philip (2014), "Philosophy for children, values education and the inquiring society", Educational Philosophy and Theory, 46(11), pp. 1203-1211. doi: https://doi.org/10.1080/00131857.2013.771443

Centa, Mateja (2013), "Umanjkanje smisla kot vzrok samomora mladih oseb", Bogoslovni vestnik, 73(3), pp. 443-451.

\footnotetext{
${ }^{2}$ This paper was prepared as part of the project Little - Learn Together to Live Together (Erasmus + ). The author also acknowledges the financial support from the Slovenian Research Agency (research core funding No. P6-0269; Ethical-religious Grounds and Perspectives of the Society and the Religious Studies in Context of Education and Violence). For useful comments on the paper I would like to thank Rolf Roew, Bruno Curko, Mateja Centa and two anonymous reviewers.
} 
Darwall, Stephen (2006), "How should ethics relate to (the rest of) philosophy? Moore's legacy", in: Horgan, Terry; Timmons, Mark (eds.), Metaethics After Moore, Oxford: Clarendon Press, pp. 17-37. doi: https://doi.org/10.1093/acprof:oso/9780199269914.003.0002

Dewey, John (1980 [1929]), The Quest for Certainty, New York: Perigee Books.

Ettenberg Aron, Israela (1977), "Moral philosophy and moral education II. The formalist tradition and the Deweyan alternative", The School Review, 85(4), pp. 513-534. doi: https://doi.org/10.1086/443366

Gardelli, Viktor; Alerby, Eva; Persson, Anders (2014), "Why philosophical ethics in school: implications for education in technology and in general", Ethics and Education, 9(1), pp. 16-28. doi: https://doi.org/10.1080/17449642.2014.890277

Gerjolj, Stanko (2015), “Od vzgoje za empatijo do vzgoje za resnico”, Bogoslovni vestnik, 75(2), pp. 211-220.

Gewirth, Alan (1968), "Metaethics and moral neutrality", Ethics, 78(3), pp. 214225. doi: https://doi.org/10.1086/291679

Globokar, Roman (2018), "Impact of digital media on emotional, social and moral development of children", Nova prisutnost, 16(3)3, pp. 545-560. doi: https://doi.org/10.31192/np.16.3.8

Horgan, Terry; Potrč, Matjaž; Strahovnik, Vojko (2018), "Core and ancillary epistemic virtues", Acta Analytica, 33 (3), pp. 295-309. doi: https://doi.org/10.1007/s12136-018-0349-4

Kirschenbaum, Howard (1992), "A comprehensive model for values education and moral education”, The Phi Delta Kappan, 73(10), pp. 771-776.

MacIntyre, Alasdair (1984), After Virtue. A Study in Moral Theory, London: Duckworth.

Moore, George Edward (1903), Principia Ethica, Cambridge: Cambridge University Press.

Nord, Warren A.; Haynes, Charles C. (1998), Taking Religion Seriously Across the Curriculum, Alexandria, VA: ASCD.

Nussbaum, Martha C. (2000), "Why practice needs ethical theory: Particularism, principle, and bad behaviour", in: Hooker, Brad; Little, Margaret O. (eds), Moral Particularism, Oxford: Clarendon Press, pp. 227-255. doi: https://doi.org/10.1017/CBO9780511527432.005

Peters, Richard Stanley (1970), Ethics and Education, $2^{\text {nd }}$ ed., London: G. Allen and Unwin.

Roew, Rolf (2017), “Zur Frage der Handlungsorientierung im Ethikunterricht”, in: Münnix, Gabriele; Rolf, Bernd (eds.), Europa Forum Philosophie 66, Nordhausen: Traugott Bautz, pp. 115-122. 
Sanger, Matthew N.; Osguthorpe, Richard D. (2005), "Making sense of approaches to moral education", Journal of Moral Education, 34(1), pp. 57-71. doi: https://doi.org/10.1080/03057240500049323

Scales, Stephen (2005), "Metaethics across the curriculum", Teaching Ethics, 5(2), pp. 1-11. doi: https://doi.org/10.5840/tej2005521

Silcock, Peter; Duncan, Diane (2001), “Acquisition and values education: Some proposals", British Journal of Educational Studies, 49(3), pp. 242-259. doi: https://doi.org/10.1111/1467-8527.t01-1-00174

Simon, Sidney B.; Howe, Leland; Kirschenbaum, Howard (1972), Values Clarification: A Handbook of Practical Strategies for Teachers and Students, New York: Hart Publishing.

Strahovnik, Vojko (2014), "Some aspects of epistemic value and role of moral intuitions in ethics education", Metodički ogledi, 21(2), pp. 35-51.

Strahovnik, Vojko (2016), "Ethics and values education”, in: Peters, Michael A. (ed.), Encyclopedia of Educational Philosophy and Theory. Continuously updated ed., Singapore: Springer, doi: https://doi.org/10.1007/978-981-287-532-7_167-1

Strahovnik, Vojko (2017), "Pomen moralne teorije za etično vzgojo", Šolsko polje, 28(1/2), pp. 45-58.

Strahovnik, Vojko (2018), Moralna teorija. O prirodi moralnosti, Zagreb: Naklada Lara.

Strike, Kenneth A. (1993), "Teaching ethical reasoning using cases", in: Strike, Kenneth A.; Ternasky, Lance P. (eds.), Ethics for Professionals in Education: Perspective for Preparation and Practice, New York: Teachers College Press, pp. 102-116.

Walsh, Adrian (2011), "A moderate defence of the use of thought experiments in applied ethics", Ethical Theory and Moral Practice, 14(4), pp. 467-481. doi: https://doi.org/10.1007/s10677-010-9254-7

Warnick, Bryan R.; Silverman, Sarah K. (2011), “A framework for professional ethics courses in teacher education", Journal of Teacher Education, 62(3), pp. 273-285. doi: https://doi.org/10.1177/0022487110398002

Žalec, Bojan (2013), “Trust, accountability, and higher education”, Synthesis philosophica, 28(1/2), pp. 65-81. 


\title{
ETIČKO OBRAZOVANJE I MORALNA TEORIJA
}

\author{
Vojko Strahovnik
}

Jedno od središnjih pitanja etičkog obrazovanja uloga je koju bi u njemu mogla ili trebala imati moralna teorija. To se ne tiče samo problema pedagoškog rada s djecom, nego $i$ ustanove profesionalnog obrazovanja i obuke učitelja $i$ drugih obrazovnih radnika. Suvremeni pristupi etičkom obrazovanju naglašavaju važnost integrativnih modela i metoda, no unutar toga nije se eksplicitno i dostatno bavilo problemom moralne teorije. Cilj ovoga rada tako se odražava u sljedećem: u prvom dijelu, predstavljamo koncept etičkog obrazovanja i polja moralne teorije; $u$ drugome, sintetički rasvjetljavamo važnost moralne teorije za etičko obrazovanje.

Ključne riječi: etika, moralna teorija, metaetika, etičko obrazovanje, integrativni pristup 